\title{
Job Satisfaction and Employee Performance at Finlays Kenya Limited in Kericho County, Kenya
}

\author{
Charles Kiprono Korir ${ }^{1}$, Dr. Priscillah Ndegwa (PhD $)^{2}$ \\ ${ }^{1}$ School of Business, Kenyatta University, Kenya \\ ${ }^{2}$ Lecturer, Department of Business Administration, School of Business, Kenyatta University, \\ Kenya
}

\section{ABSTRACT}

Employees in an organization have always been key assets and their departure could have significant effect on the implementation of the organization's performance and may eventually cause a phenomenal decline in productivity. As such, employees' job satisfaction is important in the long-term growth and success of a company. Employee satisfaction would ensure customer satisfaction and effective succession planning. The productivity and efficiency of human resource depend upon a number of dynamic factors which range from personal factors to organizational policies. Job satisfaction being one of the very most important factors which impact the productivity of human resources. Human resource is therefore one of the most important assets in any organization which serves as an engine in the organization for providing a sustainable source of energy and service delivery. This study sought to establish the relationship between job satisfaction and employee performance at Finlays Kenya Limited. The specific objectives of the study were to determine the influence of work environment, remuneration, promotions and training and development on employee performance at Finlays Kenya Limited. The study was anchored on Hertzberg's Two Factor Theory, Locke's Range of Affect Theory and Maslow's theory. The job characteristics model has also been used to anchor the study. The study used descriptive research design. The target population of this study comprised of permanent employees at Finlays Kenya Limited who total to 641 ranging from engineers, accountants, high level managers, middle level managers and supervisors. Stratified random sampling was used to select the sample size of 128 which is 20 percent of the total study population. The validity of this research employed the econometric technique to establish the relationship between job satisfaction and employee performance at James Finlays Kenya Limited. Cronbach's Alpha was used to measure the co-effective of internal consistency and in this way reliability of the instrument. Primary data was collected using a semi structured questionnaire administered to respondents. Data collected was analysed through descriptive and inferential statistics by the use of SPSS. Findings were presented by use of tables, frequencies, percentages, means and standard deviation. The findings of the study will be useful to the manufacturing and service industry players. The study concluded that job satisfaction has a significant direct influence on employees' performance. Salary and other rewards constitute the most important element of job satisfaction besides promotions/job position which enables employees to do the job and meet their expectations. At the same time, leadership is necessary for employees' performance with senior managers at prime position to influence performance of their employees through job satisfaction. The researcher therefore recommends that, organizations should invest highly on training and development of their employees, their remunerations, and promotions as well as improve their working conditions in order to realize the desired employees' output.

Key Words: Work Environment, Remuneration, Promotion, Training and Development, Job Satisfaction, Employee Performance, Finlays Kenya

DOI: $10.35942 /$ jbmed.v2i2.119 


\section{[IJCAB}

\section{Cite this Article:}

Korir, C., \& Ndegwa, P. (2020). Job Satisfaction and Employee Performance at Finlays Kenya Limited in Kericho County, Kenya. International Journal of Business Management, Entrepreneurship and Innovation, 2(2), 82-97. https://doi.org/10.35942/jbmed.v2i2.119

\section{Introduction}

Employee performance and productivity is of major concern in any economy worldwide. Choudry (2009) in his study Determinants of Labor Productivity, notes that Africa and south Asian countries (except India) performance in labor productivity is not very encouraging. Labor productivity level in 2005 in sub- Saharan Africa economies was the lowest among all regions. He further emphasized the need to pay more attention on average education attainment level, producing productive employment to attract foreign direct investments. Human resources management practices have significant impact on organizations productivity. Abdulla (2009) points out that training and development, team work, human resources planning and performance appraisal are correlated with an organizations business performance. Globally and focusing on Pakistan, Motowidlo (2003) explains that job performance is the totality of all those expected behaviors that individuals bring to their working environment and give values to the organization. Those employees who are considered as the high performers usually get the chances of hiring earlier in the organization as compare to the low performers. Therefore, the success of every organization is based on the performance of employees jobs (Pushpakumari, 2008). The higher the performance of employees, the higher the chance for getting the maximum productivity (Sonnentag \& Frese, 2002). For every organization, that wishes to increase its productivity, they need to find out all those methods through which they can increase the performance of their employees. Pushpakumari (2008) stated that for the achievement of high-performance employees need to work hard. Satisfied employees are motivated when they are motivated, they will work hard and will be committed to the organization and will achieve the goals of the organization as well.

Regionally, in a study conducted in 2018, In Egypt, high turnover of labor is one of the key challenges facing companies, according to surveyed employers. The average turnover across large firms is 536 employees per year while in medium-sized firms, the turnover reaches 20 employees per year and in small-sized firms the average decreases to five employees annually (Ehab, 2015). Ehab (2015) indicated that the main reasons for this phenomenon are higher wages and better opportunities without any further explanation. As turnover is closely related to job satisfaction, as previously mentioned, it is expected that employees with higher wages, more stable jobs, access to benefits like paid and sick leaves and social security will witness higher levels of job satisfaction, and accordingly firms will witness less turnover rates. In Kenya, scholars like Kiragu (2002), Obong'o (2009) and Kim (2005) had indicated that there are factors that created differences in how public sector organizations coped with change. The main factor was that the performance aims of most public sector organizations differed from firms in the private sector whose strategic transformation were to produce profit. Public organizations were normally limited in terms of flexibility and autonomy as there was political interference, broad accountability and performance expectations continuously shift.

The labour market today is growing and changing fast. It is the responsibility of the leader in the organization to adapt to these changes to be able to make the organization profitable. To be able to do this, it is crucial to satisfy the key employees in the organization since they are the ones that drive the company forward. According to Young (2006), companies are faced 
with a challenge of people leaving to join other companies. The average worker is changing jobs ten times between ages of 18 and 37 continuously. Young asserts that one answer to this issue is to believe that you can purchase knowledge to replace what you are losing. McCrea (2001) suggests that employees today change jobs frequently and do not have the company loyalty that existed 30 years ago when your valued employees were hired. The article, 'The battle for brainpower' (2006), also states that loyalty to employers is fading therefore companies need to raise productivity by managing talent better. The hunt for talent has gone global as globalization has created demands and opportunities for most employees. Employees in an organization have always been key assets as their departure could have significant effect on the implementation of the organization's business plans and may eventually cause a parallel decline in productivity. As such, employee satisfaction is important in the long-term growth and success of a company. Employee satisfaction would ensure customer satisfaction and effective succession planning (Mello, 2007). Employee satisfaction would also improve investor's confidence, as they are concerned with the organization's capacity to perform in such ways that would positively influence the value of their investment in the company, hence there is no question that uncontrolled employee turnover could damage the stability of the company.

The productivity and efficiency of human resource depend upon a number of dynamic factors which range from personal factors to organizational policies. Job satisfaction is one of the very most important factors which impact the productivity of human resources. Human resource is considered as one of the most important assets in any organization which serves as an engine in the organization for providing a sustainable source of energy and service delivery (Muhammad \& Wajidi, 2013). Shahu and Gole (2008) in their research analyse the effects of job satisfaction on performance. They summed up their findings on a factor that work satisfaction should be considered by the organization as an important plan which needs to be extended in order to improve employees performance. In general, employee job satisfaction has been defined as 'a function of the perceived relationship between what one wants from one's job and what one perceives it as offering' (Portoghese, Galletta, \& Battistelli, 2011). Job satisfaction is an attitude that people have about their jobs and the organizations in which they perform these jobs (Al Zubi, 2010).

Job satisfaction has got three dimensions. Firstly, it is an emotional response to a job situation. The only way we can come to a conclusion on this is through observation of the employee e.g. the time they get to work how they work. Secondly, job satisfaction can be determined by how well outcomes meet the expectations. An example is the fact that if the salary is commensurate to work done and is equitable, the organization members are likely to develop job satisfaction. Thirdly, job satisfaction can be viewed as representing a combination of related attitudes (Gathungu \& Wachira, 2013). According to Kalpana (2013), Job satisfaction and motivation are considered as some of most essential components of work life, and one of the major factors that have influence on the individuals' performance at the work place. Job satisfaction affects the physical and mental capabilities of employees. An individual need to maintain a healthy body \& mind to be able to perform physical and mental activities in the best possible way in his/her work place. In general, job satisfaction and motivation can contribute to the enhancement in the employee performance. Job satisfaction has been repeatedly and constantly prized in both humanistic and financial terms. It has been observed that the employees who do quality work are usually the ones who are satisfied with their job. Satisfied employees tend to have high retention rates; they are more dedicated to the organization and tend to yield higher job performances (Arif \& Chohan, 2012). This study therefore sought to establish the job satisfaction measures and levels among employees at the Finlays Kenya Limited based in Kericho County and determine the influence they have 


\section{IIJCAB}

on the performance of employees in the firm. The study will look at work environment, remuneration, promotion and training and development as job satisfaction indicators and their influence of employee performance.

Finlays was founded in 1750. As a fully owned subsidiary of the John Swire and Sons Ltd Group, the company has extensive tea and horticultural interests in East Africa and Sri Lanka complimented by global trading, packaging and extraction activities, with the primary markets being in the UK and US. The main business areas are horticulture, tea estates, tea trading, tea extraction, beverage packing and logistics and services. Flamingo Holdings, a fully owned subsidiary of Finlays, is a substantial horticultural business that includes growing, processing, packaging, marketing and distribution of cut flowers and premium prepared fresh vegetables, supplying several leading UK retailers. Finlays Kenya Ltd is now one of the largest growers in Kenya, with over 100 million stems of Fairtrade certified cut flowers grown each year. According to Finlay (2011), the company produces over 40 million kilos of black tea every year from tea estates in Sri Lanka and Kenya. The tea estates in Kenya are Rain Forest Alliance accredited. Tea trading with volumes in excess of 100 million kilos each year is carried out from offices in the UK, Kenya, Dubai, Malawi, Vietnam and the USA. As the world's largest supplier of quality tea extracts, Finlays Kenya Limited deals with all of the world's top beverage companies. Beverage Packing is carried out from the state-of-the-art facilities in the UK and Sri Lanka, blending, sourcing and packaging, primarily private label tea and coffee for customers in the UK, the Middle East and Japan. Logistics and services are carried out in Sri Lanka with the first modern refrigerated storage facility of any scale and a variety of primarily service-related businesses in both Sri Lanka and in Pakistan.

This reputation is based upon over 100 years in this business. They take pride in their product expertise, attributable to loyal and knowledgeable workforce and an ongoing investment in research and development. The Company also takes pride in the longevity of customer relationships and the partnerships forged. Finlays globally employs over 50,000 people, many of whom reside on the tea estates and flower farms in Sri Lanka and Africa and for whom housing, schooling and medical facilities are provided (Finlay, 2011). The company is very serious about its responsibilities towards her people and their communities as well as the local and global environment. Their flower farms and many of their tea estates are Fair Trade accredited. Finlay Flowers is a producer member of KFC with silver and gold certification. However, while operating to high ethical and environmental standards and audited by numerous external audit bodies, they recognize that the environmental and social situation is never a constant and are committed to continually looking for ways to improve their performance. It operates mainly in Kericho. The company produces 23 million kilograms of made tea. They are self-sufficient in sustainable timber and power ( $85 \%$ hydro-electric) and employ nearly 16,000 people who live on their estates and are provided, and their families, with housing, schooling and medical services, this amounts to more than 11,000 houses, 106 hospital beds, 25 medical dispensaries, 14 primary schools, 17 nursery schools and one secondary school.

Although violence has been reported in the Rift Valley Province since 1991, the Company as well as many other organizations has not been affected to the scale witnessed during the PostElection Violence of 2007. Despite of this, the company managed to meet the demand for flowers and all the tea factories kept running. Further, no lives were lost in the Company during the violence (Finlays, 2011). This calls for action from all those concerned especially in the light of the fear of a repeat (Yamano, Yuki \& Gitau, 2010). The company has seven factories, five process black tea while two process instant tea. According to the Managing Director, the company remains committed to the plantation sector of their business but have 


\section{[IJCAB}

been motivated by a desire to narrow the focus of their operations geographically and managerially and therefore the range and extent of the challenges that they must address and to which they must do justice. However it is the case that the downstream businesses of packaging, tea extracts and tea trading benefit directly in some instances, and always by association, from a shared knowledge derived from their ownership of plantations. It is also the case that some of these businesses are based in Kericho and there are opportunities there and in Sri Lanka for diversification of land use as well as the production of tea (Hogg, 2006).

\section{Statement of the Problem}

Recognizing that employees are the critical resources in any organization necessary to enhance performance, most organizations now are focusing on the factors that improve on their job satisfaction. The element of job satisfaction has however been ignored in many organizations as a precursor to employee performance and consequently the goal achievement for any organization. Woodruffe (2000), emphasized on the importance of training and skills development of employees applied through the underlying principle of continuous organizational learning. According to Champion-Hughes (2001 job satisfaction results from many influential factors such as rewards, job position and working environment and that such imperative aspects of job satisfaction include nature of job (intrinsic), tangible rewards (extrinsic) and relationships with people at work (interpersonal). The elements of satisfaction are strongly influenced by direct working environment which encompasses controlling regulations, job stress, interpersonal conflicts, team work, and sufficient provision of funding and facilities (Kotler, 2003). Jobs act as a major source of wealth and livelihood for people, so it has a direct effect of extrinsic rewards associated with work and would result into of employees' satisfaction (Boggie, 2005). Employee satisfaction is increasing in importance, as the competition for talent is high and still growing. It is not hard for a competitor to compete with individual elements of employment such as salaries and benefits. Boyens (2007) focuses on the reasons of involuntary turnover, voluntary turnover, and promotion for employees to leave a particular company. Furthermore, he says that the two types of turnover are the most devastating for organizations. The effect of voluntary turnover includes loss of performance, knowledge, expertise, relationship, and loss of the time and resources that it took to train the employee. This leads to a feeling of insecurity and affects the performance of the employees who are left because of the constant disruption of services and too much change which as a result affects the general performance of the company.

Employee turnover rates have, within the last decade become a nationwide epidemic. Employees no longer feel the sense of company loyalty that once existed (Odembo 2013). Increasing numbers of corporate mergers and acquisitions have left employees feeling detached from the companies that they served and haunted by concerns of overall job security. This has led the employees to focus more on job hunting rather than performance thereby hurting the general performance of the firms. With the problem of increasing employee turnover in the agriculture and manufacturing industry, one wonders if the goal of the Kenya government concerning the growth and expansion of the sector is going to be realized. Chowdhury and Nazmul (2017) opine that it therefore calls for a greater action to be taken to find out how to retain the organization's valuable employees and the factors likely to affect them to remain in the industry to help achieve sector and firm objectives and that of the Finlay Kenya Ltd. This research study seeks to investigate the factors that may influence employee satisfaction and how these factors affect performance of employees at Finlays Kenya Limited. 


\section{IJCAB}

\section{Objectives of the Study}

The main research objective was to establish the influence of job satisfaction on employee performance at Finlays Kenya Limited in Kericho County, Kenya.

The specific objectives of the study were;

i. To establish the influence of work environment on the performance of employees at Finlays Kenya Limited.

ii. To examine effect of remuneration on employee performance at Finlays Kenya Limited.

iii. To establish the influence of promotion on employee performance at Finlays Kenya Limited.

iv. To determine effect of training and development on employee performance at Finlays Kenya Limited

\section{Theoretical Review}

The study was anchored on three theories that explain job satisfaction and employee performance in organizations. They include; Hertzberg's Two Factor Theory, Locke's Range of Affect Theory and the Job Characteristics Model.

\subsection{Hertzberg's Two Factor Theory}

In 1959, Frederick Herzberg, a behavioural scientist proposed a two-factor theory or the motivator-hygiene theory. According to Herzberg, there are some job factors that result in satisfaction while there are other job factors that prevent dissatisfaction. According to Herzberg, the opposite of Satisfaction is No satisfaction and the opposite of Dissatisfaction is No Dissatisfaction. The research conducted by Hertzberg determined what people actually want from their jobs. The respondents had to describe work situations in which they felt good (satisfied) or bad (dissatisfied) in their jobs. The feedback received was then categorized into satisfaction or dissatisfaction (Kreisman, 2002). The characteristics related to job satisfaction included advancement, recognition, the work itself, achievement, growth and responsibilities. Hertzberg referred to these characteristics as 'motivators'. The characteristics related to dissatisfaction, which included working conditions, supervision, interpersonal relationships, company policy and administration were referred to as hygiene factors (Robbins, 2001). According to Schermerhorn (1993), Herzberg's two-factor theory is an important frame of reference for managers who want to gain an understanding of job satisfaction and related job performance issues. Schemerhorn asserts that Herzberg's two-factor theory is a useful reminder that there are two important aspects of all jobs: what people do in terms of job tasks (job content), and the work setting in which they do it (job context). Schermerhorn suggests that managers should attempt to always eliminate poor hygiene sources of job dissatisfaction in the workplace and ensure building satisfier factors into job content to maximize opportunities for job satisfaction. This theory is relevant and significant to this study in that it recognizes that employees have two categories of needs that operate in them and that both should be addressed. This theory therefore can guide a researcher in establishing determinants of employees' satisfaction in a firm like Finlays Kenya Ltd.

\subsection{Locke's Range of Affect Theory}

Locke's Range of Affect Theory was postulated by Edwin A. Locke in 1976 and is the most popular theory of job satisfaction. This theory determines job satisfaction through a difference which exists between what an employee wants from a job and what the employee is getting from the job. Further, the theory states that how much one values a given facet of work (e.g. the degree of autonomy in a position) moderates how satisfied/dissatisfied one 


\section{IIJAB}

becomes when expectations are/aren't met. When a person values a particular facet of a job, his satisfaction is more greatly impacted both positively (when expectations are met) and negatively (when expectations are not met), compared to one who doesn't value that facet.

According to this theory (Baron \& Greenberg 2003), the impact of the various factors of job satisfaction can be determined if we know the value a person places on a particular workrelated outcome. The greater the value placed on each factor, the greater the shift in satisfaction changes that will be produced. This theory also advocates that if too much value is placed on a particular factor; stronger feelings of dissatisfaction will occur. Locke's theory is therefore multifaceted and greatly specific to each individual. According to this theory Baron and Greenberg (2003), indicated that the impact of the various factors of job satisfaction can be determined. In this aspect, if an organization knows the value placed on each factor, the greater the shift in satisfaction changes that will be produced. This theory also advocates that if too much value is placed on a particular factor, stronger feelings of dissatisfaction will occur. Locke's theory is therefore multifaceted and greatly specific for each individual. This can be illustrated in the following example: Two employees that perform the same task at the same place of work may experience the same level of satisfaction but in totally different ways. The one employee may be strongly influenced by the physical aspects of the job whilst the other employee may be influenced by the challenge and variation inherent in the job (Locke, 1976). In contrast, Baron and Greenberg (2003) argue that although Locke's Theory has not been extensively researched, a great amount of emphasis placed on values alludes that job satisfaction may rise from factors. This theory as well is significant to this study as it is essential to guide in determining the factors that contribute towards the varying degrees of job satisfaction or job dissatisfaction.

\subsection{Maslow's Theory}

The Maslow's theory of job satisfaction is attributed to Maslow (1954). Maslow's work focused on what has commonly been referred to as a "hierarchy of needs" with the major premise being that lower order needs (physiological, security, and belongingness) need to be satisfied before individuals can fulfil their higher order needs (esteem and self-actualization). This hierarchical model presumes that when a lower order need is not satisfied it preoccupies the individual and precludes attention to higher order needs. Individual behaviour is motivated by a desire to satisfy the need that is most important at a specific point or period in time. Maslow maintained that all higher order needs are seldom totally satisfied and that individuals may proceed up the hierarchy without absolute fulfillment of basic needs. On the contrary, he concluded that for most individuals lower order needs are regularly satisfied (Derlin \& Schneider, 1994). The theory interfaces with this study due the fact that the retention of workforce is dependent on satisfaction in the work place. If an employee's needs are met in their current work situations, they are feel settled and will not be migrating to other employers.

\subsection{Job Characteristics Model}

Hackman and Oldham (1976) argued that Job Characteristics Model, is a framework to study how particular job characteristics impact on job outcomes, including job satisfaction. The model states that there are five core job characteristics (skill variety, task identity, task significance, autonomy, and feedback) which impact on three critical psychological states (experienced meaningfulness, experienced responsibility for outcomes, and knowledge of the actual results), in turn influencing work outcomes (job satisfaction, absenteeism, work motivation). The five core job characteristics can be combined to form a motivating potential score (MPS) for a job, which can be used as an index of how likely a job is to affect an employee's attitudes and behaviours. The first three dimensions, that is skill variety, task 


\section{[IJCAB}

identity and task significance is unified to ensure that the job is more meaningful. If these characteristics are evident in a job, then the incumbent will interpret the job as more valuable and worthwhile. Many employees may complain that their jobs lack variety and creativity, therefore rendering the job boring and dull. Robbins (2001) adds that if the first three dimensions were included in a job, this would make the job more interesting, worthwhile and valuable to the incumbent. This will therefore have a favourable effect on job satisfaction. The jobs that include autonomy will equip workers with a sense of personal responsibility and self-fulfilment. If a job possesses feedback, incumbents will become more wary about their performance and effectiveness (Robbins, 2001). This model is relevant to this study due to the fact that an interplay of various factors as emulated by the model have a different effect on the human resource in terms of the organizations' perspective. Job satisfaction is a psychological experience that each employee encounters in their individual capacity and yield different results in the work place.

\section{Conceptual Framework}

The independent variable will job satisfaction measures which include work environment, remuneration, promotion and training and development while dependent variable is employee performance at Finlays Kenya Limited.

\section{Independent Variables}

\section{Dependent Variable}

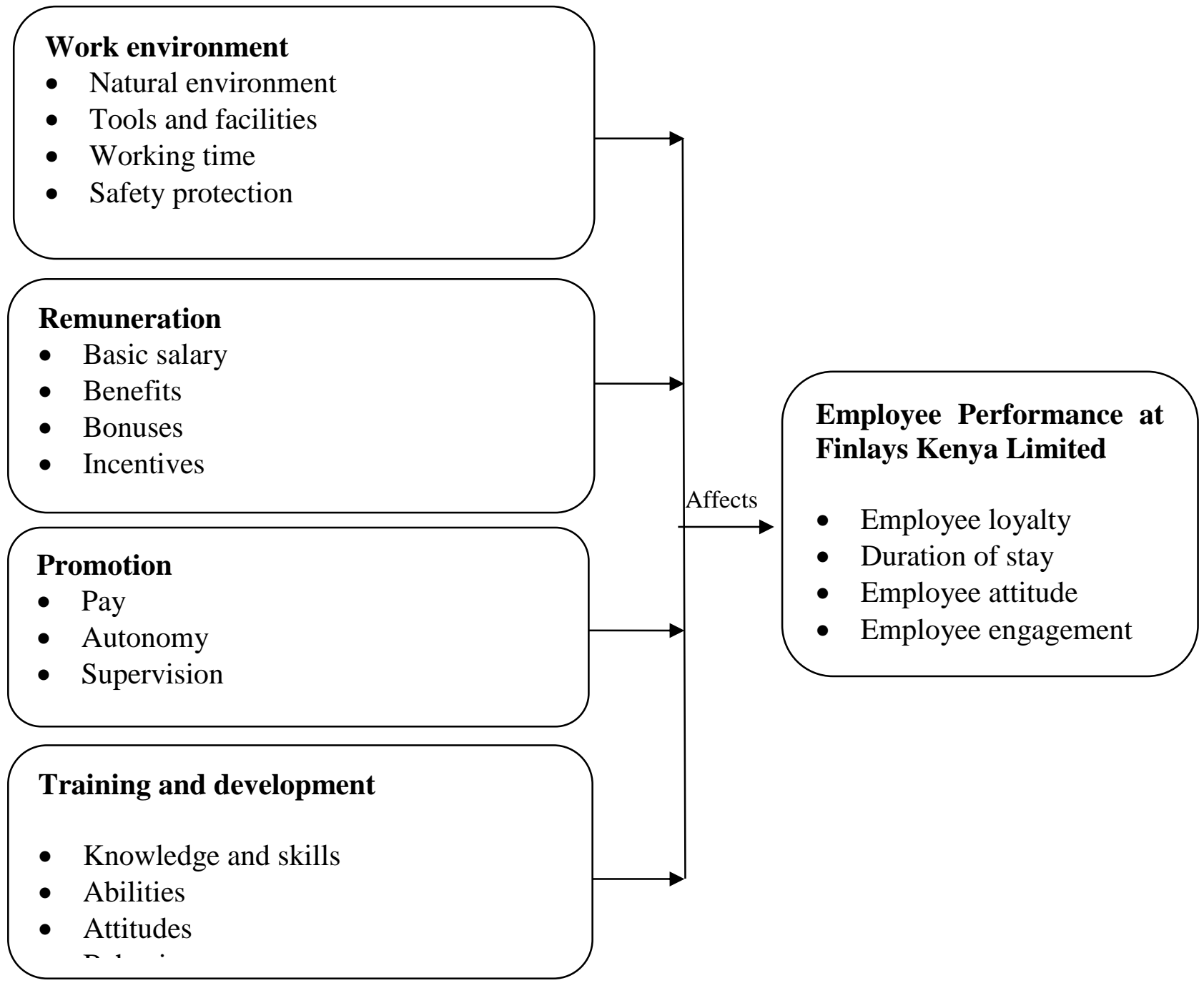

Figure 1: Conceptual Framework 


\section{IIJAB}

\section{Source: Researcher (2020)}

\section{Research Methodology}

The study adopted a descriptive design which Mugenda and Mugenda (2003) described as a research design which is a systematic, empirical inquiring into which the researcher does not have a direct control of independent variable as their manifestation has already occurred or because they inherently cannot be manipulated. Target population for study were the employees at the Finlays Kenya Limited head offices in Kericho County. According to the FKL (2018), there are 641 permanent employees working in various sections at the firm ranging from engineers, accountants, high level managers, middle level managers and supervisors. Stratified random sampling technique was used to obtain a representative sample since population of interest is not homogeneous. Owing to the big number of target population and given the time and resource constraints, the sampling at least $10 \%$ is recommended by Mugenda and Mugenda (2003). This study therefore used a sample of 128 respondents or $20 \%$ of the population drawn from all staff at the five categories at the Finlays Kenya Limited in Kericho County, Kenya.

Primary data was collected by the help of a semi-structured questionnaire. The close-ended questions provided more structured responses to facilitate tangible recommendations while the open-ended questions provided additional information that had not been captured in the close-ended questions. The study used primary data which was collected through selfadministered questionnaires to the permanent staff at the tea farms and factories of the firm in Kericho County. Questionnaire were preferred since the staff are knowledgeable and educated hence they could read and respond accordingly. After information accumulation, an exhaustive check was done on the polls previously coding and utilizing Statistical Package for Social Sciences (SPSS). The essential information gathered through polls was dissected utilizing exceed expectations to get existing relationships. The connections illuminated the analyst on presence or non-presence of a connection between the job satisfaction and employee performance at Finlays Kenya Limited. Quantitative data was presented through tabulation, percentages, mean, standard deviation and frequencies.

\section{Research Findings}

This section was based on variable relationship statistics as given by correlation analysis, coefficient of determination, analysis of variance and regression coefficients. Correlation was done to determine the linear relationship between each of the variables against the other as shown in Table 1. Pearson Product Correlation Coefficients for these relationships were derived at $95 \%$ confidence level, 2-tail test.

\section{Table 1: Correlation Analysis}

\begin{tabular}{|c|c|c|c|c|c|c|}
\hline & & 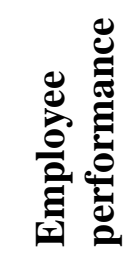 & 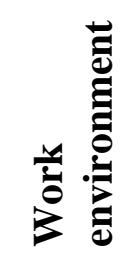 & 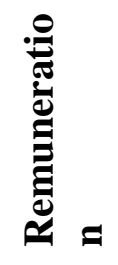 & 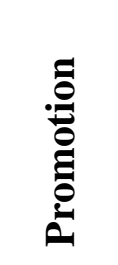 & 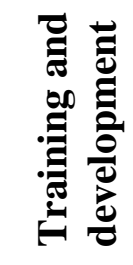 \\
\hline \multirow[t]{4}{*}{ Pearson Correlation } & Employee performance & 1.000 & 0.663 & 0.750 & 0.742 & 0.678 \\
\hline & Work environment & 0.663 & 1.000 & 0.543 & 0.429 & 0.884 \\
\hline & Remuneration & 0.750 & 0.543 & 1.000 & 0.461 & 0.581 \\
\hline & Promotion & 0.742 & 0.429 & 0.461 & 1.000 & 0.449 \\
\hline
\end{tabular}




\begin{tabular}{|c|c|c|c|c|c|c|}
\hline & & 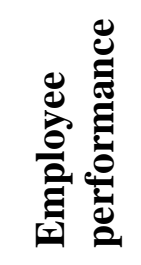 & 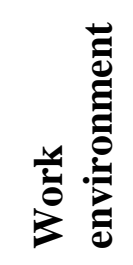 & 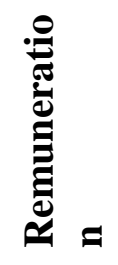 & 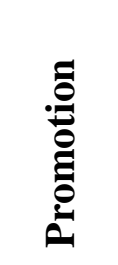 & 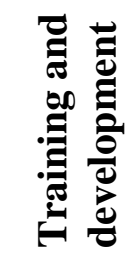 \\
\hline & Training and development & 0.678 & 0.884 & 0.581 & 0.449 & 1.000 \\
\hline \multirow[t]{5}{*}{ p-Value } & Employee performance & & .000 & .000 & .000 & .000 \\
\hline & Work environment & .000 & . & .000 & .000 & .000 \\
\hline & Remuneration & .000 & .000 & . & .000 & .000 \\
\hline & Promotion & .000 & .000 & .000 & . & .000 \\
\hline & Training and development & .000 & .000 & .000 & .000 & . \\
\hline
\end{tabular}

Source: Researcher (2020)

All variables were found to be positively correlating to each other with employee performance having correlation index of $0.663,0.750,0.742$, and 0.678 for work environment, remuneration, promotion, and Training and development respectively. The highest correlation was between training and development and the work environment $(0.884)$ implying that the two variables are key in determining employees' performance. All correlations had $\mathrm{p}$-Value $<0.05$ confirming that each variable was significantly correlating with the other.

Coefficient of determination $\left(\mathrm{R}^{2}\right)$ was used to determine the extent to which explanatory variables (predictors) explained any change in the predicted variable. That is, the degree to which change in employee's performance by 1 unit is explained by job satisfaction.

Table 2: Coefficient of Determination

\begin{tabular}{cccc}
\hline $\mathrm{R}$ & R Square & $\begin{array}{c}\text { Adjusted } \mathrm{R} \\
\text { Square }\end{array}$ & $\begin{array}{c}\text { Std. Error of the } \\
\text { Estimate }\end{array}$ \\
\hline $.897 \mathrm{a}$ & 0.805 & 0.797 & 0.340 \\
\hline
\end{tabular}

a. Predictors: (Constant), Training and development, Promotion, Remuneration, Work environment

\section{Source: Researcher (2020)}

Results in Table 4.5 show an R-Square of 0.805 with the standard error of estimate being 0.340. This implies that job satisfaction (through training and development, promotion, remuneration, and work environment) explains changes in employees' performance up to 80.5 percent. The remaining 19.5 percent is explained by other factors that are not envisaged in this study.

Analysis of variance (ANOVA) was generated to determine the spread of the mean of variables and in particular spread between variables and spread within data.

Table 3: Analysis of Variance

\begin{tabular}{lccccc}
\hline Model & $\begin{array}{c}\text { Sum of } \\
\text { Squares }\end{array}$ & df & $\begin{array}{c}\text { Mean } \\
\text { Square }\end{array}$ & F & Sig. \\
\hline Regression & 48.722 & 4 & 12.181 & 105.112 & $.000 \mathrm{a}$
\end{tabular}


International Journal of Business Management, Entrepreneurship and Innovation, Volume 2, Issue 2, 2020, PP 82-97, ISSN 2707-8027

[IJCAB

\begin{tabular}{lccccc}
\hline & $\begin{array}{c}\text { Sum of } \\
\text { Squares }\end{array}$ & df & $\begin{array}{c}\text { Mean } \\
\text { Square }\end{array}$ & F & Sig. \\
\hline Residual & 11.820 & 102 & 0.116 & & \\
Total & 60.542 & 106 & & & \\
\hline
\end{tabular}

a. Predictors: (Constant), Training and development, Promotion, Remuneration, Work environment

b. Dependent Variable: Employee performance

\section{Source: Researcher (2020)}

As shown in Table 3, F-Calculated $(4,102)=105.112$ at 2-tail test and 95\% confidence level. Results also show p-Value $=0.000<0.05$. This further confirms that, the attainment of high level of performance through productivity and efficiency is dependent on a satisfied workforce as satisfied works work harder and effectively for the betterment of the organization (Ssegawa, 2014). They are committed to their organization and therefore their energy is focused on the achievement of the organizational goals. Thus, every organization tries to create and maintain a satisfied workforce in order to achieve its objective and to remain competitive. Organizations are thus placing considerable reliance on their individual employee performance to gain high productivity in the organization. In addition, different employees in an organization yield different levels of performance under the various circumstances according to their satisfaction level, motivation level, behaviour and many other reasons contribute in yielding various levels of performance by various individuals (Arif \& Chohan, 2012). Sutherland (2004) contends that companies with high quality human capital perform better in marketplace, and deliver higher and more consistent returns to shareholders, than companies with mediocre workers. Shahu and Gole (2008) in their research analyze the effects of job satisfaction on performance. They summed up their findings on a factor that work satisfaction should be considered by the organization as an important plan which needs to be extended in order to improve employee's performance.

This was done to generate a regression model as shown in Table 4.

Table 4: Regression Coefficients

\begin{tabular}{lccccc}
\hline & \multicolumn{2}{c}{ Unstandardized Coefficients } & \multicolumn{3}{c}{ Standardized Coefficients } \\
& $\mathrm{B}$ & Std. Error & Beta & $\mathrm{t}$ & Sig. \\
\hline (Constant) & 0.544 & 0.177 & & 3.076 & 0.003 \\
Work environment & 0.131 & 0.071 & 0.174 & 1.847 & 0.038 \\
Remuneration & 0.296 & 0.042 & 0.396 & 7.079 & 0.000 \\
Promotion & 0.356 & 0.041 & 0.441 & 8.653 & 0.000 \\
Training and & & & & & \\
development & 0.068 & 0.069 & 0.096 & 0.984 & 0.048 \\
\hline
\end{tabular}

a. Dependent Variable: Employee performance

\section{Source: Researcher (2020)}

From the findings, when all the predictors (that is work environment, remuneration, promotion and training and development) are held constant, employees' performance would remain at 0.544 out of 5 units on a five-point Likert-type scale. In addition, when work 


\section{IIJAB}

environment increases by 1 unit, employees' performance increases by 0.131 units. The same case happens when remuneration, promotion, and training and development separately increases by 1 unit leading to increase in employees' performance by $0.296,0.356$, and 0.068 respectively. All the predictors had p-Value $<0.05$ at $95 \%$ confidence level implying that they were all individually significant in influencing employees' performance. This once more positions the four variables as major predictors for employees' performance. The model can

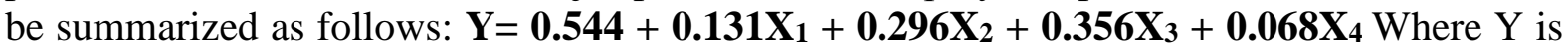
the dependent variable (employee performance at Finlays Kenya Limited), $\mathrm{X}_{1}=$ Work environment, $\mathrm{X}_{2}=$ Remuneration, $\mathrm{X}_{3}=$ Promotion, $\mathrm{X}_{4}=$ Training and development.

In summary, employees' performance will vary because the conditions under which a job is performed can be different - from those completely comfortable to those very difficult and dangerous to employees' life and health. Jobs with difficult working conditions may perform only those employees who meet specific requirements in terms of age, sex, qualifications, health, physical and mental condition and psycho-physiological and psychological capabilities. Myles (2012) adds that a company that seeks to train and develop its employees well and reward them for their performance has its employees in turn motivated and thus are more likely to be engaged in their work hence improving performance and loyalty to their company. These same employees, being the point of contact with customers will provide better service, leading to more business and more referrals from the satisfied customers. The increase in sales through referrals and repeat businesses will translate into an increase in business profits thus improving shareholders' investment. The shareholders are therefore benefiting from increased returns on their investment in the business. In addition, good financial performance also attracts new shareholders to the business. Suppliers will be eager to do business with the company due to its financial strength and its positive reputation. The company is therefore able to negotiate friendly purchase terms with suppliers. Moreover, findings of this study do align with Markova and Ford (2011) who mentions that the real success of companies originate from employees' willingness to use their creativity, abilities and know-how in favour of the company and it is organization's task to encourage and nourish these positive employee inputs by putting effective reward practices in place. Lotta, (2012) also contends that motivated employees are more productive, more efficient and more willing to work towards organizational goals than the employees who are experiencing low levels of motivation.

\section{Conclusions and Recommendations}

Job satisfaction has a significant direct influence on employees' performance. Salary and other rewards constitute the most important element of job satisfaction besides promotions/job position which enables employees to the job as interesting and meeting their expectations. At the same time, leadership is key for employees' performance with senior managers at prime position to influence performance of their employees through job satisfaction. It can also be concluded that employees do value their career progression in the company. Thus, organizations that invest on employees training and development, promotion, remuneration, as well as proper work environment are likely to register effective and efficient performance from their employees.

Given limitation and findings of this study, the researcher recommends that, organizations should invest highly on training and development of their employees, their remunerations, and promotions as well as improve their working condition in order to realize the desired employees' output. Policy makers should also endeavour to incorporate in the labour laws clauses that favour a conducive working relationship between employees and their employers to ensure a symbiotic relationship. Managers and supervisors in both public and private firms 


\section{IIJCAB}

should consider making gaining more competence through personal development and trainings. This will enable them apply leadership quality that will yield the desired output.

\section{REFERENCES}

Abdulla, J. \& Djebavni, R. (2011). Determinants of Job Satisfaction in the UAE. A Case Study of Dubai police, 40(1), 126-146.

Al Zubi, H. A. (2010). A Study of Relationship between Organizational Justice and Job Satisfaction. International Journal of Business and Management, 5 (12), 102-109.

Arif, A., \& Chohan, A. (2012). How job Satisfaction is influencing the organizational citizenship behaviour (OCB): A study on employees working in banking sector of Pakistan. Interdisciplinary Journal of Contemporary Research in Business, 4(8), 7488.

Babin, B. J. \& Boles, J. S. (1996). The effects of perceived co-worker involvement and supervision support on service provider role stress performance and job satisfaction. Journal of Retailing, 72(1), 57-75.

Bargraim, J., Cunningham, P., Potgieter, T. \&Viedge, C. (2007). Organisational behaviour: A contemporary South African perspective. Pretoria: Van Schaik.

Barton, G. M. (2002). Recognition at work. Scottsdale: World at Work.

Chan, S. H. \& Qiu, H. H. (2011). Loneliness, job satisfaction, and organizational commitment of migrant workers: empirical evidence from China. The international Journal of Human Resource Management, 22(5), 1109-1127.

Chawla, S. \& Renesch, J. (2006). Learning organisations: Developing cultures for tomorrow's workplace. New York: Productivity Press.

Choudry, A. (2009). Challenging colonial amnesia in global justice activism. In Kapoor, D. (ed.). Education, decolonization and development: Perspectives from Asia, Africa and the Americas. Rotterdam: Sense.

Chowdhury A. M., \& Nazmul H., (2017). Factors affecting employee turnover and sound retention strategies in business organization: a conceptual view. Problems and Perspectives in Management, 15(1), 63-71.

Christine, P \& Pearson, C. (2009). How Toxic Colleagues Corrode Performance. Harvard Business Review, 87(4).

Cooper, D. R. \& Schindler, P. S. (2001). Business Research Methods. $7^{\text {th }}$ ed. Boston: McGraw Hill International Edition.

Cooper, D. R. \& Schindler, P. S. (2011). Business Research Methods, $11^{\text {th }}$ ed. Boston: McGraw-Hill Irwin International Edition.

Danish, Q. D., \& Usman, A. (2010). Impact of reward and recognition on job satisfaction and motivation: An empirical study from Pakistan. International Journal of Business \& Management, 5(2), 159-167.

Deming, W. E. (1990). Sample design in Business Research. New York: Johnwiley \& Sons.

Derlin, R., \& Schneider, G.T. (1994). Understanding job satisfaction: Principals and teachers, urban and suburban. Urban Education, 29, 63-89.

Dessler, G. (2012). Human Resource Management. New York: Prentice Hall.

Döckel, A., Basson, J. \& Coetzee, M. (2006). The effect of retention factors on organisational commitment: an investigation of high technology employees. SA Journal of Human Resource Management, 4(2), 20-28.

Eggemeier, F. T. (2011). Effects of sensory modality and task duration on performance, workload, and stress in sustained attention. Human Factors, 46(2), 219-233.

Ehab, M. (2015), "Skills of fresh graduates between supply and demand in the egyptian labor market", Unpublished Paper 


\section{IJCAB}

Emberland, J. S. \& Rundmo, T. (2010). Implications of job insecurity perceptions and job insecurity responses for psychological well-being, turnover intentions and reported risk behaviour. Safety Science, 48, 452-459.

Farrington, S. M. (2009). Sibling partnership in South African small and medium-sized family businesses. Unpublished doctoral thesis, Nelson Mandela Metropolitan University, Port Elizabeth.

Fincham, R. \& Rhodes, P. (2005). Principles of organizational behaviour. 4th Edition. New York: Oxford University Press.

Ganzach, Y. (1998). Intelligence and Job Satisfaction. The Academy of Management Journal, $41,526-539$

Gathungu, J., \& Wachira, H. W. (2013). Job satisfaction factors that influence the performance of secondary school principals in their administrative functions in Mombasa district, Kenya. International Journal of Education and Research, 1(2), 257-270.

Gautam, M., Mandal, K., \& Dalal, R. S. (2006). Job satisfaction of faculty members of veterinary sciences: an analysis. Age, 36(5.91), 0-92.

George, J. M., \& Jones, G. R. (2002). Organisational behaviour. (3rd ed.). New Jersey: Prentice Hall.

Golshan, N. M., Kaswuri, A. H., Aghashahi, B., Amin, M., \& Wan Ismail, W. K. (2011). Effects of motivational factors on job satisfaction: An empirical study on Malaysian Gen-Y administrative and diplomatic officers. In 3rd International Conference on Advanced Management Science (Vol. 19, No. 7).

Govender, S. \& Parumasur, S.B. (2010). The relationship between employee motivation and job involvement. School of Management Studies, University of KwaZulu-Natal.

Grant, A. M., Fried, Y., \& Juillerat, T. (2010). Work matters: Job design in classic and contemporary perspectives. Forthcoming in S. Zedeck (Ed.), APA handbook of industrial and organizational psychology. Washington, DC: American Psychological Association.

Hackman, J. R., \& Oldham, G. R. (1976). Motivation through the design of work: Test of a theory. Organizational Behaviour \& Human Performance, 16(2), 250-279.

Hair, J. F., Anderson, R. E., Tatham, R. L., \& Black, W. C. (1998). Multivariate data analysis with readings. Englewood cliff, NJ: Prentice-Hall.

Herzberg, F., Mausner, B., Synderman, B. (1959). The motivation to work. NY: Wiley.

Hui, M. K, Kevin, Au, \& Fock, H. (2004). Empowerment Effects across Cultures. Journal of International Business Studies, 35, 46-60.

Hunjra, A. I., Chani, M. I., Aslam, S., Azam, M. \& Rehman, K. U. (2010). Factors effecting job satisfaction of employees in Pakistani banking sector. African Journal of Business Management, 4(10), 2157-2163.

Hussin, A. B. (2011). The relationship between job satisfaction and job satisfaction and job performance. Centre for graduate studies; Open University Malaysia.

Iqbal, A. (2010). An empirical assessment of demographic factors, organizational ranks and organisational commitment. International Journal of Business and Management ,5(3), 16-27.

Jackson, S. L. (2011). Research methods and statistics: a critical thinking approach. $4^{\text {th }}$ Edition. Cengage Learning.

Kabir, M. (2011), Factors affecting employee job satisfaction of pharmaceutical sector, Australian Journal of Business and Management Research, 1(9), 113-123.

Kawada, T., \& Otsuka, T. (2011). Relationship between job stress, occupational position and job satisfaction using a brief job stress questionnaire (BJSQ). Work, 40(4), 393-399. 


\section{IIJCAB}

Kim, S. (2005). Individual-level factors and organizational performance in government organizations. Journal of Public Administration Research and Theory, 15(2), 245261.

Kiragu, K. \& Mukandala, R. (2003). Public Service Pay Reform: Tactics, Sequencing and Politics in Developing Countries - Lessons from Sub-Saharan Africa. Washington D.C: World Bank,

Kreisman, B. J. (2002). Identification of the drivers of employee dissatisfaction and turnover. Austin, TX: University of Texas

Lai, H-H. (2011). The influence of compensation system design on employee satisfaction. African Journal of Business Management, 5(26), 1078-10723.

Ling, Y. H., \& Hong, L. (2010). How intellectual capital management affects organizational performance: Using intellectual capital as the mediating variable. Human Resource Management Student Newspaper, 10(1), 1-27.

Locke, E. A. (1976). The nature and causes of job satisfaction. Handbook of industrial and Organizational Psychology. Chicago: Rand McNally.

Locke, E., \& Latham, G., (1991). A Theory of Goal Setting \& Task Performance. The Academy of Management Review. 16. 10.2307/258875.

Motowidlo, S. J., \& Kell, H. J. (2012). Job performance. Handbook of Psychology, Second Edition, 12.

Mugenda, O. \& Mugenda, A. (2003). Research methods: quantitative and qualitative approaches. (1st ed.). Nairobi: African Centre for Technology Studies (ACTS).

Obong'o, S. O. (2009). Implementation of performance contracting in Kenya. International Public Management Review, 10(2), 66-84

Odembo, S. A., (2013). Job satisfaction and employee performance within the telecommunication industry in Kenya: a case of Airtel Kenya limited. Kenyatta University.

Prasetya, A. \& Kato, M. (2011). The Effect of Financial and Non-Financial Compensation to the Employee Performance. The 2nd International Research Symposium in Service Management. Yogyakarta, Indonesia.

Society for Human Resource Management (2012). SHRM 2012-2013 Human Capital Benchmarking Report.

Spector, P. E., Cooper, C. L., Sanchez, J. I., O'Driscoll, M., Sparks, K., Bernin, P., \& Miller, K., (2002). Locus of control and well-being at work: how generalizable are western findings. Academy of Management Journal, 45(2), 453-466.

Suhartini, (1995). Analysis of factors affecting intention performance improvement lecturer at private universities in Yogyakarta. Surabaya, Program Pascasarjana Unair

Swarnalatha, C, \& Sureshkrishna, G. (2013). Role of employee engagement in building job satisfaction among employees of automotive industries in India. International Journal of Human Resource Management and Research, 3 (1).

Tietjen, M. A. \& Myers, R. A. (1998). Motivation and job satisfaction. Management Decision, 36/4, 226-231.

Van Wyk, R. \& Adonisi, M. (2008) The role of entrepreneurial characteristics in predicting job satisfaction. South African Journal of Economic \& Management Sciences, 11(4), 391-405.

Vlosky, P. \& Aguilar, X. (2009). A model of employee satisfaction: Gender differences in cooperative extension. Journal of Extension, 47(2), 1-15.

Wagner, J. \& Hollenbeck, J. (2010). Organizational Behaviour: Securing competitive advantage. New York: Routledge.

Washburn N. (2009). Why Profit Shouldn't be Your Top Goal. Harvard Business Review, 87(12). 


\section{[IJCAB}

Wentzel, K. R. \& Wigfield, A. (2009) Handbook of Motivation at School. New York: Routledge.

Westover, L.A. (2010). Enhancing long-term worker productivity and performance: The connection of key work domains to job satisfaction and organizational commitment. International Journal of Productivity and Performance Management, 59(4), 372-387.

Woodroffe, R. (2000). Predators and people: using human densities to interpret declines of large carnivores. Anim. Conserve. 3, 165-173

Yamano, T., Gitau, R., \& Tanaka, Y. (2010). Haki Yetu (It's Our Right): Determinants of Post-Election Violence in Kenya. GRIPS Policy Research Center.

Yin, R. K. (2003). Case Study Research: Design and Methods. California: Sage. Thousand Oaks.

This is an open-access article published and distributed under the terms and conditions

of the cc) (i) (8) Creative Commons Attribution 4.0 International License of United States unless otherwise stated. Access, citation and distribution of this article is allowed with full recognition of the authors and the source.

Authors seeking to publish with an Internationally Peer Reviewed Journals should consider https://www.ijcab.org/ by writing to the Editor at editor@ijcab.org or submitting online at https://journals.ijcab.org/journals/index.php. The articles must be quality and meet originality test. 